\title{
THE CHALLENGE OF SOCIO-ECONOMIC COHERENCE FOR POLAND'S ECONOMIC POLICY IN CONTEXT OF TRANSFORMATION PROCESSES
}

\section{Michał Gabriel Woźniak}

Cracow University of Economics, Applied Economics Department, ul. Rakowicka 27, 31-510 Kraków, Poland, e-mail: wozniakg@uek.krakow.pl

\begin{abstract}
The article focuses on Polish socio-economic coherency in the European and regional context during post WWII period. The author argues that the source of this incoherency are faulty mechanisms, its economic, social and regional policies which were before the transformation based on central coordination of strategies and later, prior to Polish membership in the EU, due to autonomic processes. Much of the weaknesses after accession of Polan to the EU have been due to mixed policies practiced. This has been based on competitive harmony in which economic, social and territorial coherence that is augmented by open coordination methods at union, national, regional and sub-regional levels. It is not sufficient applying socio-economic coherence to processes of eliminating disproportions existing in regional development. Their practical utility requires taking cognizance of the specificity of local material, human and social capital resources. The key issue of socio-economic coherence is harmonizing the development of all aspects of human living.
\end{abstract}

Key words: socio-economic coherence, economic policy, Poland

JEL Classification: 010, 043, P14

DOI: $10.2478 / \mathrm{v} 10135-009-0004-5$

Národohospodářský obzor - Review of Economic Perspectives ISSN 1804-1663 (Online), ISSN 1213-2446 (Print)

http://nho.econ.muni.cz/en

(C) Masarykova univerzita 


\section{THE CHALLENGE OF SOCIO-ECONOMIC COHERENCE FOR POLAND'S ECONOMIC POLICY IN CONTEXT OF TRANSFORMATION PROCESSES}

\section{Michał Gabriel Woźniak ${ }^{1}$}

\section{Introduction}

Signum specifikum of modern European model of capitalism that is being projected by EU convey the idea of competitive harmony with central coordination of strategies realized by goals being endorsed by various EU organs and individual countries through open procedures. This dual approach of regulation is aimed at guaranteeing socioeconomic coherence in a spatial set-up.

Socio-economic coherence is understood in EU-policies as harmonizing economic efficiency and justifiable social inequalities cultivated in spatial set-up. Thus, there arises a question about the applicability of, so understood, policy of socio-economic coherence, to solve real social and economic problems in the post-socialist countries. The aim of the paper is to present Polish experience in this policy.

The author advances an hypothesis that efficient policy requires an holistic approach. Thus, the application of state regulatory activities is needed to harmonize quality of life in all aspects of human existence. In this context, the paper discusses successes and failures of Polish policies as practiced since the introduction of market economy, as well as prospects of attaining socio-economic coherence owing to her accession to EU.

\section{How is the EU socio-economic coherence understood?}

The idea of coherence policy is widespread in the most important EU documents. It was introduced by the Treaty of Rome and proved by the EU-Treaty. Thus, the idea of this policy was evaluated by many economists of various theoretical streams. The analysis conducted by Wim Kok (2004), and publications of W.W. Lewis (2005), W. Bieńkowski and J.J. Radło (2006), S. Golinowska (2002), M. Klamut and E. PanekCybulska (2006), and A. Kukliński (2009) are well known in Poland.

The idea of coherence is understood in EU documents as harmonizing socio-economic development processes while eliminating disproportions in regional development. It's goal is to set real convergence processes in motion which is understood as reducing disparities in social prosperity in spatial set-up. Economic coherence is attainable by strictly following model indicators of economic performance very often measured as GDP per capita or modification of it through economic aggregates. Social coherence, on the other hand, should guarantee the attainment of model indicators of social development, especially in reference to the labour market and living conditions with emphasis being paid to eliminating poverty, exclusion and marginalization.

\footnotetext{
${ }^{1}$ Cracow University of Economics, Applied Economy Department, ul. Rakowicka 27, 31-510 Krakow, Poland, e-mail: wozniakg@uek.krakow.pl
} 
The search for economic coherence is a follow-up of West European idea of integration. Solidarity, democracy, respect for human rights, right to freedom and self-identity as well as the principle of financial support for the poor by the rich were acceptable fundamental values in post-war Europe. Although the principle of solidarity is accepted as fundamental, it is undergoing crisis in its confrontation with hard principles of global capitalism. Other values and principles of integration are likewise being verified. They are being validated in the latest EU governing documents. According to article III-220 of the reform treaty "The EU is aiming at reducing regional disparities of the least privileged. As for the regions here mentioned special attention is paid to rural regions, areas undergoing industrial and territorial transformation, which are suffering consequences of serious and perennial natural and demographic difficulties such as the most northern sparsely populated regions as well as trans-border and mountain insular regions".

Such an approach to socio-economic coherence is strictly connected with the process of harmonizing institutional order, regulatory and social policy mechanisms. The decisive factor of socio-economic coherence in EU countries is competitive harmony that is supported with policies of harmonizing economic efficiency and justifiable social inequalities cultivated at union, national, regional and local levels. This is corroborated by the desire to eliminate development barriers being results of economic and social disparities, as well as aiming to ensure quality life for local societies free of the consequences of civilization's underdevelopment.

The implementation of socio-economic coherence with full involvement of mechanisms and instruments of central coordination of strategies under market economy, however, leads to subordinating various procedures for harmonizing aspects of human life to political objectives. In practice, this seemingly greatly complicated process is reduced to the elimination of regional growth disparities. European Commission experts and officers have viewed regional disproportions as the key obstacle to political and market integration, as the source of socio-economic conflicts and economic growth that would permit bridging the development gap with more developed countries.

The attainment of socio-economic coherence is, however, more complex than is reflected in the model indicators adopted for EU planning procedures. First and foremost, it relies on autonomous processes connected with the state of human and social capital as well as on institutional marketing tools. This is not meant to underrate the importance of from-the-top initiated stimuli. There exists no other way except by exploiting awareness and taking steps to test societal ingenuity in creating standards to improve functioning of markets. These activities need not be underestimated. In undertaking these steps, local irrationalities in human and social capital development cannot be overlooked.

Thus the fundamental issue of central coordination of strategies is the creation of institutional and material forum for the popularization of thought and performance principles aimed at realizing personal benefits while recognizing the functional utility of interested persons as regards improving life quality in all areas of human existence. It is all about harmonizing development not only in areas of economics, consumption, social or political but also in technology, nature and biology, thought (human capital) and divine. 


\section{Some inherited economic incoherencies in Poland}

Poland inherited an economic structure that is incoherent with demands of open markets from her erstwhile centrally planned economy. This incoherency is evident in not relating production patterns to demand in open markets, high indicators of material use in production with its associated low efficiency of physical capital, labour which in essence led to low real incomes and incapability of the economy to service foreign credits. Spatial planning also led to territorial incoherency. Preference for the development of heavy industry or giant complexes in certain regions led to pathological development of old regions with strong labour class that manifested itself in form of (Kukliński 1983, pp. 21; Potoczek 2003, pp. 263):

- predatory exploitation of natural resources, obsolete energy transmitters, intensifying water and air pollution

- discrimination in the demand for technical infrastructural, social, agricultural forestry development as well as not keeping up with technological progress,

- faltering and inefficient urbanization although they were able to develop few new industrial regions, expand several large companies and to locate several smaller industries in rural areas.

Marketing processes were to amend the consistently increasing incoherency with the global economy through the unification of regulatory systems to achieve competitive harmony which should in effect yield the marketing model that operates in EU. The Polish economy has thus become coherent with model solutions existing in EU but has not yet been concluded in certain aspects of regulating harmonization process. Such areas include uniform monetary system, cooperation in areas of coordination and implementation of fiscal policies, harmonization of tax system, procedural and institutional solutions in respect of social issues.

As regards practical issues, it turned out that constructing socio-economic coherence based on marketing principles is an unusually complex process. This view is validated by results of empirical studies not only in its international context but also internally, including regions and sub-regions. Although some substantial success was achieved in respect of economic coherence, it was, nonetheless, at a huge social cost which resulted in non-realization of issues of social coherence. Instigating pro-effective corporate performance lasted much longer than initially planned whilst the opening of the market, though with care, exposed the competitive weaknesses of national enterprises especially at times of worsening economic climate. Although great success was achieved, the lowest indicators in respect of development catching-up among new EU member countries were registered in Poland just before her accession to the EU. Such areas of concern according to Eurostat data include (see: table 1):

- GDP per capita which was just 52.3\% of EU27 average in 2006 (Latvia - 52.5\%; Lithuania - 55.5\%; Slovakia - 63.5\% ; Hungary - 63.5\%, Estonia - 65.3\%, Czech Republic - 77.6\%)

- employment level of 51\% for 2004 was the least among new EU member countries from Central and Eastern Europe as against the over $60 \%$ in the other countries, 
- FDI inflow amounted to $0.4 \%$ of GDP in 2004 as against over $1 \%$ of GDP for other new member countries, which amounted to $\$ 1,500$ per person in Poland as against $\$ 3,000$ for other new member countries,

- consistent fall to $0.5 \%$ share of R\&D expenditures in GDP in 1997 which has remained the east among EU27 countries since it has not grown significantly,

- the disparity between highest and lowest quintal of income levels among EU27 which equaled 6.6 in 2005 was relative high in Poland comparing to other new member countries.

The process of political transformation resulted in worsening disproportions in regional development in Poland. The economic crisis exacerbated traditional disproportions between less developed regions of eastern Poland which is made up of extensive rural area, small and medium sized towns dominated by collapsing industries and regional development characterized by varied economic structure, developed transport infrastructure, a well developed business enhancing institutional framework, well equipped with human capital and enterprise culture as well as higher than average cost of living and remuneration.

Studies of regional convergence show that Poland is a country with a much established spread of relative GDP per person both within the provinces and sub-regions. This trend is accompanied by relative poverty of provinces and dependent sub-regions which are often large cities. The only observable model of convergence in Poland is that of club convergence at NUTS 2 and NUTS 3 levels, i.e., the independently growing similarity of most wealthy and least wealthy regions (Wójcik, 2007).

\section{Delaying issues of social coherence}

The threats of public finance crisis that dangled over Poland in the 1990s and the pressure of liberalization adopted from the Washington consensus made subsequent Polish governments treat, as part of reforms undertaken by them, issues of social harmony as marginal, especially the intensifying property and income disproportion, corruption, medical conditions, upbringing and education, combining professional and family life, declining population and befitting ageing. Marginalization of social policies prior to the accession of Poland to the EU was accomplished at the instance of foreseeable huge costs of access to EU which had to be covered from the central budget. The burden of paying about 2 billion Euros to the EU during first few years of membership and that of 20-25\% personal input to projects realized with structural funds as well as delays in respect of accruing benefits from co-financing structural programmes and social coherence made it impossible to take any actions in this respect. 


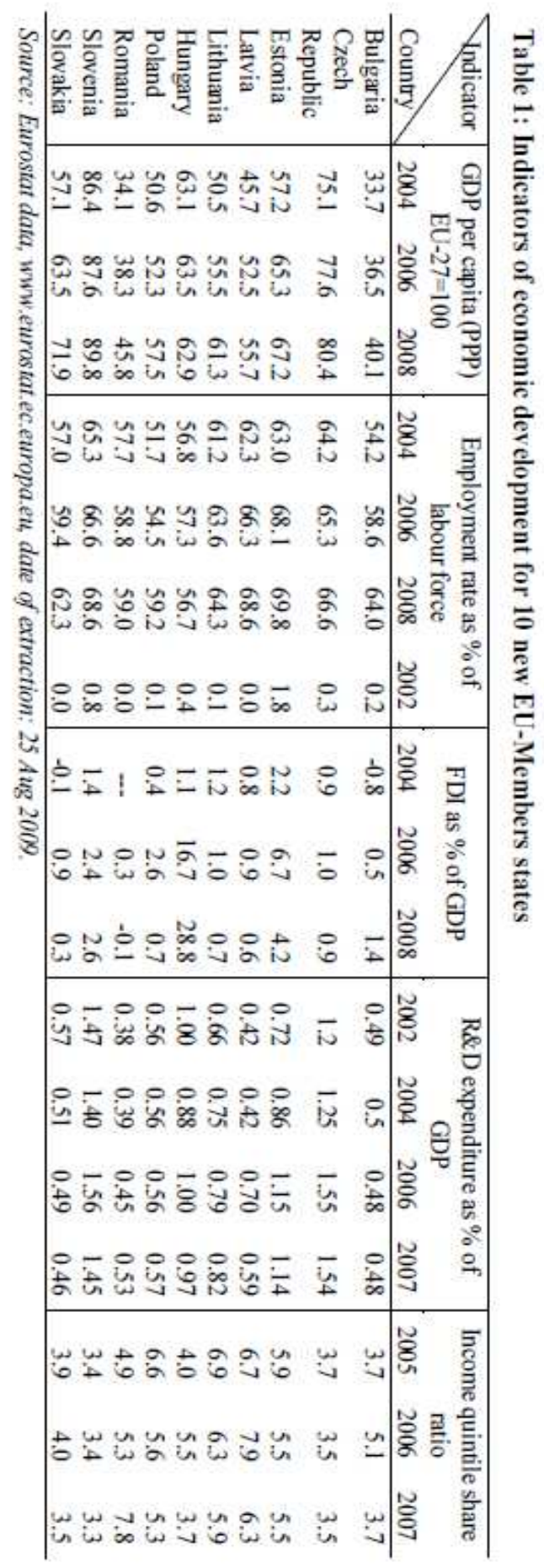


This does not, however, mean that issues of social coherence were never dealt with prior to EU membership. Until then they had been carried out in the context of rationalization of social expenditures. Such actions were taken not really with a desire to curb social problems but to put in check the rather high budget deficit and threats of being entrapped in foreign debts. It is worthy to recall that Poland in 1990 inherited external debts amounting to $77.9 \%$ of her GDP from the centrally planned economy (Woźniak, 1997 , p. 84). This was even after the debts had been restructured with the cancellation of $50 \%$ of the debts owed to the Paris Club in 1991 and $45 \%$ to the London Club in 1994. Excessive investment growth in relation to balance of payment capacity during 1995-1998 together with the recession that followed brought Poland under the threats of being entrapped in foreign debts once again.

Steps taken to rationalize public expenditures included the following:

- departure from pay indexation in 1996 in favour of pay-price mechanisms, its reduction to $20 \%$ in 1999 as well as its limitation to price indexation and restraining automatic indexation of benefits beginning in 2004.;

- restricting jurisdiction in disability system way back in 1997 which made it possible to obtain surplus resources for pension funds;

- limiting criteria for granting social protection for the unemployed which resulted in only $15 \%$ unemployed receiving allowances in 2003 ,

- refusal to raise in real terms expenses on education, health care and social welfare which inevitably meant significant reductions in real terms per beneficiary due to inflation and fast growing costs in these sectors.

The outcome of such social policy was a drastic decline in quality of social development, increasing destructive conflicts and social inequalities that lead to widening poverty which finally culminated in civilizational backwardness of some social strata and regions.

Some experts have not only accused subsequent governments of lack of professional will and disrespect in issues of social coherence but also of abuse of the commonly understood liberal economic harmony ${ }^{1}$ in trying to enforce national fiscal stability. In reality, balancing close to the brinks of being entrapped in foreign debts coupled with excessive state budget tightening left no meaningful maneuvering space for social coherency.

\section{Strategic targets of socio-economic coherence policy in Poland 2007-2013}

The issue of socio-economic coherency could and indeed had to be taken up only after crossing the threshold of fast economic growth and accession to EU. Poland's access to the EU meant her inclusion in the implementation of one of its key policies, i,e., coherence policy whose objective is to promote harmonious development of the entire EU25 territory through activities that enable the curtailing of disproportions in levels of regional development. Owing to these activities gains in the area of social, economic and territorial coherence of individual countries and the Union as a whole as well as the

\footnotetext{
${ }^{1}$ Similar opinions were expressed by Z. Sadowski, T. Kowalik, S. Golinowska and others at a forum by the Council of Socio-economic Strategies. ref.: Racjonalizacja..., 2004).
} 
bridging of development gaps and convergence with other countries and regions can be anticipated.

Every member state benefiting from EU funds prepares, on the basis of EU Strategic Principles, a National Framework Strategy for 2007-2013 to enhance economic growth and job creation, the National Coherence Strategy. This document enunciates an analysis of the socio-economic position of a country and its regions, formulates the country's key developmental challenges for subsequent years as well as states objectives aimed at achieving the Union's coherence in three aspects (economic, social and territorial), allocating financial resources for their realization of each programme and schemes.

A synthetic measure of the degree of realization of strategic objectives is the rate of decline in GDP per capita at national and regional levels. Currently, this index is about $50 \%$ of the prevailing EU25 average. The implementation of NSRO objectives should raise this index to two-thirds of EU average. Sustaining such rate of real convergence would have allowed the attainment of EU average growth levels within the lifespan of one generation. The detailed allocation of structural funds as well as coherence funds for 2007-2013 is presented in table 2.

Table 2: Allocation of EU Structural Funds in Poland for 2007-2013

\begin{tabular}{l|c|c|}
\hline Structural Funds & Amount in billion Euro & $\begin{array}{c}\text { Contribution of total } \\
\text { budget }(\%)\end{array}$ \\
\hline $\begin{array}{l}\text { Infrastructure and } \\
\text { environment }\end{array}$ & 27.9 & 41.9 \\
Regional Operating & 16.6 & 24.9 \\
Programs & 9.7 & 14.6 \\
Human capital & 8.3 & 12.4 \\
Economic Innovation & 2.3 & 3.4 \\
$\begin{array}{l}\text { Development of Eastern } \\
\text { Poland }\end{array}$ & & 0.8 \\
Technical Assistance & 0.5 & \\
\hline
\end{tabular}

Source: $w w w$.funduszestrukturalne.gov.pl

The global financial crisis impacts of which lead to decline in average rate of GDP growth during 2009-2010, increasing unemployment and deteriorating state of national and local governments will dampen the realization of the National Strategic Development objectives set for 2009-2013. Hence the more crucial are the challenges facing socio-economic coherence policies. This is a call for the release of huge resources from Structural Funds and Coherence Funds during the years burdened with effects of the global crisis, for ensuring financial investment resources through an expansive monetary policy and acceptable fiscal preferences within a harmonized fiscal system as well as by holding back declines in internal demands especially from those most strongly touched by the crisis.

\section{General-system problems of efficient model of socio-economic coherence}

Mechanisms for attaining socio-economic coherence have not been fully comprehended. In case of extreme model solutions, it is assumed that this process is achieved either 
through spontaneous growth generated by efficient markets as a result of which linking resources with results becomes more effective, or through the intervention of state authorities. In practice however, we observe the interplay of mixed mechanisms. The influence of global liberal economy, territorial association of production and development, the concept of grass-root regional development often referred to in publications as a local development concept is currently gaining popularity. This concept is replacing earlier paradigmatic state management of regional development processes, coherence initiated from above. The state in the new dispensation plays a complementary role by setting up institutions, instruments and procedures to mobilize the local populace (Gorzelak 2000, pp. 99-102).

Grass-root initiated local development is based mainly on a region's internal resources, tied with the specifics of the local area as well as external situation. Faced with contemporary challenges, the role of non-material factors - especially those connected with social and human capital (social ties, culture and performance in their widest meaning as well as the view of local populace on innovation) - is being emphasized (Hrynkiewicz 2000, pp. 53-55). Though, several authors question the ability of grassroot initiated mechanisms to bridge development gaps in regions with weak internal potentials. Halting the vicious peripheral, socio-economic incoherency cycle requires the attainment of the so-called "critical mass" factors that inspire processes of adjusting to development challenges (Grosse, 2007). When it comes to Poland, external development incentives in the form of public assistance based on principles of subsidization offered by national governments and EU support funds for innovative activities of local businesses, transiting into a learning region, inflow of external capital, as well as infrastructural development are applicable in all regions. We are, however, confronted with the difficult issue of diversifying the intensity of allocation of public assistance. The burning question is if it is possible to halt the vicious circle of poverty in regions where weaknesses in internal potentials pose high risks of efficient utilization of inflowing external assistance. Consequently, there is need to identify the initial motives for business location, factors facilitating growth and encouraging stagnation as well as capacity to develop competitive potentials.

It is hard fostering enduring competitiveness and an environment that facilitates the achievement of self benefits through activities oriented at the customer and common goal by applying activities that improve micro-economic efficiency in isolation from self-responsibility. This short-sighted strategy has negative effects on long-term economic efficiency and social coherence. It is sometimes a justifiable perverse resistance against legislative control of competitive harmony which in essence is an impediment to the state being furnished with effective tools in its anti-corruption fight. It eventually imposes nationwide or even intra-organizational norms that encourage esteem which does not facilitate legal transparency and ordinarily do not serve to introduce standards of quality of life, work, public service or protection of spiritual values that strengthen subjectivity and dignity of the individual or social groups that have survived the passage of time.

The key challenge of institutional harmony that enhances socio-economic coherence is the elimination of institutions that protect privileges not justified by economic effectiveness and social responsibility. Nevertheless, it should be remembered that economically harmful and socially unjustified privileges are often the product of 
despotic manipulation of the majority by the political, media or legal elite of responsibility (immunity protection and insufficient control due to very weak institutions and citizenry).

A law-abiding state that is mindful of the fact that competitive harmony and social coherence cannot be a weak nation, devoid of possibilities of fulfilling its duties. The effective fulfillment of these duties, even when decreed by higher regulations, can be difficult in view of the specificity of the local human capital, inherited absurdities in human capital development, differences in regional economic development as well as other barriers. Recognizing this specificity of local productive resources will be helpful in introducing methods of coordinating development strategies that is being promoted by the EU. Although these are time consuming procedures and are threatened with the risk of consensus and huge transactional costs, the question that arises is of the availability of any other more effective method for harmonizing growth in all spheres of human existence. The alternative for sure is market coordination as a part of global competition that would enhance higher economic efficiency for entities with technological advantage in areas of human and social capital as well as institutional solutions. This alternative is however always saddled with problems of social coherence and high poverty rate, exclusion and the incapability syndrome. It should be noted, however, that without the civic society all activities that aim at socio-economic coherence would yield half-hearted results. It is impossible to create a civic society without knowledge and motivation that would enable them co-operate for the common good of local societies, social responsibility of members of representative organs for the development of local societies. The way towards this objective is through appropriate institutional reforms that compel changes in procedures of performance in public administration.

The fact is that increasing productivity of activities has become a much more urgent challenge for Poland and other new EU member countries than to its earlier signatories. These countries are facing the challenge of reducing the development gap. This is similar to harmonizing development in traditional sectors and new economies (ICT) or eliminating absurdities of human capital, institutional barriers to businesses or creating law-abiding governments and civic societies. Although both globalization and regionalization exhibit similar growth challenges irrespective of economic, political or social settings national economies do not impose analogous responses. Effective growth stimulation processes by the state require the adaptation of performance methods to the hierarchy of goals and their degree of urgency which always manifest themselves in a given social and material environment. The creation of socio-economic coherence in Poland at the beginning of the 21st century requires overall transformation that will facilitate the adaptation of territorial development in physical, cultural, economic and terminological aspects to the demands of a common European market. This for economic policy means being ready for openness, competitiveness, efficiency, fairness, innovation and exploiting the strength existing in a varied local society (Conception, 1995, pp. 41-43).

\section{Local boundaries for socio-economic coherence policy}

Despite Poland's assumption of EU acquise commonautaire, businesses continue to function in an institutional environment plagued with post-communist burden of thought 
patterns and behavior that tolerate varied privileges for selected employee, political and business groups. In social environment dominated by injustice and with interest groups wielding varied penetrating powers, liberalization can be threatened, as it can be exploited to acquire new privileges.

Poland is a country highly prone to outflow of human capital due to its excessive growth and not being aligned to demand trends in the labour market as well as due to social standards and pay levels that have remained much lower than in EU15. Hence the main issue is not that of investing in human capital development but that of curbing absurdities of its growth and creating more quality job places. Similarly, in countries with high rate of unemployment the policy of creating job places become the key requirement for socio-economic coherence whilst the low inclination to take up employment calls for a review of social policies with the aim to strengthen mechanisms of self responsibility and eliminating ethically unfair and economically unjustified social privileges.

The high and yet increasing risk of hindering human capital development, restricting innovation, declining productivity as well as the burden of pension and social benefit funds on the market sector is also not unconnected with dwindling population in Poland. The ageing society translates into more pressure on high taxes and labour costs, insufficient incentives for state and business reforms, weak economic growth as well as falling quality of life which invariably complicates issues of bridging development gaps. These population decline related processes do not encourage investments in human capital and thus create favourable climate for economic emigration of qualified labour force that is already depleted by population declines.

Counteracting these processes requires systemic family-oriented policies to eliminate existing discriminatory mechanisms, a large part of costs of creating human capital in connection with demographic processes and bringing up of younger generations. The characteristic approach of neo-liberal state concentration based on the creation of economic foundations of growth is of course indispensable but not sufficient in the attainment of socio-economic coherence. An equally significant factor is appreciating its social aspects, especially aspects of developing human capital free of absurdities inherited from a centrally planned economy and of existing market economy. Ignoring the social prerequisites of development can not lead to expansion of a knowledge-based economy and marketing network structures and neither can it popularize customer and society service strategy through innovation value system (Chan Kim, Mauborgne, 2005, pp. 30-39) without which the issue of competitive and commercialization asymmetry will continue to prevail in all aspects of human existence thus resulting in spiraling threats in various facets of human life. Socio-economic coherence, in this context, becomes a key challenge if the economic sector is to foster the improvement in quality life in all aspects of human existence.

\section{Limitation of socio-economic coherence resulting from the Lisbon Strategy}

The approach to socio-economic coherence as contained in the Lisbon Strategy is, in the opinion of the author, doubtful from the theoretical and practical perspective. The most important weaknesses of the socio-economic concept of the Lisbon Strategy are the 
profusion of desirable goals and scattered programmes, instrumental achievement of social objectives often not coherent with economic effectiveness, circumventing the problem of logistic incoherence of bureaucratic procedures with pro-effective mechanisms of marketing activities, and ignoring, for political and ideological reasons, needs for deregulation to increase the efficiency of productive resources.

Weaknesses of the Lisbon Strategy can be curbed. Thus it is necessary to re-direct its priorities towards a proper definition of justifiable social inequalities and harmonizing them with tenets of economic efficiency. This requires consecutive elimination of sources of imperfect competition, elimination of inherited absurdities of human capital development, and facilitating the modernization of reflective human capital thus empowering businesses to create knowledge-based economy (K-bE), proper definition and security of consumers' rights, transparent definition of property rights and their guarantee, elimination of yet existing bureaucratic bottle-necks mitigating against pluralism in business activities, as well as a new social policy aimed at eliminating economically unjustified and socially unfair privileges granted certain social groups. Only such institutional environment can encourage strategy of socio-economic development based on consistent increase in productivity, development of human capital and new social policy of justifiable social inequalities.

The pattern adopted in the modernization of reflective human capital is squarely dependent on changes in social capital, which defines possibilities for exploiting existing resources of knowledge in the process of cooperation. The epitome of this correlation between human and social capital is expressed in the influence of changes in social capital (i.e. declining social trust) on the usage of human capital and the extent of it not being used as a result of low level social trust, high optimism, corruption, crime, unemployment, increasing poverty and social exclusion. In order to make manifest the creative capabilities of human capital investments in human beings knowledge, skills and motivation must be employed in the economic process just like other forms of capital. The contrary situation means that such investment in human beings will only serve as cost functions in the production process. In order to fully exploit creative capacities of both human and intellectual capital, it is necessary to combine them with social capital, i.e. such specific types of knowledge and skills which generate trust, ability to co-operate and teamwork.

It is not enough to treat socio-economic coherence as a procedure for eliminating disproportions in regional development. This is only possible when the development of all spheres of human existence is harmonized. A holistic approach to socio-economic coherence is a necessary prerequisite for the proper identification of its fundamental properties. These factors are connected with the state of human and social capital as well as institutional harmony. The mutual dependency of the factors of socio-economic coherence ensure that growth strategies that facilitate the harmonization of economic efficiency with justifiable inequalities may occur in market situations based on central strategic co-ordination equipped with institutions aimed at modernization of reflective human capital, elimination of inherent absurdities in its development as well as of causes of depreciation in human capital. It is only then one can speak of freedom of choice as participants in a market will become freed from excessive bureaucratic regulations that increase transactional costs of economic growth whilst reducing market competitiveness. 
In creating a conducive environment for objectives mentioned above, the measures proposed in the National Strategy of Coherence (Polska..., 2006) ought to be fully employed. The peripheral or secondary concept of regions can thus be overcome. Success achieved by the Silicon Valley, USA and some regions of Finland (Grosse, 2007) corroborate this opinion. Yet the reality of the situation shows that it is a complex task and has been successful only in few occasions. Surmounting peripheral view is even more difficult mainly due to inertia and pretentious attitudes of local societies swayed by arguments of internal weakness and inability to change situations. The strong dependence of a region's development on national policies does not advance this course either. The path to surmounting peripheral nature is not indeed state subsidy for regional development but rather insisting on infrastructural development, especially the modernization of reflective human capital (Woźniak, 2008, pp. 605-614). In the case of peripheral regions, it involves the simultaneous realization of three huge modernization i.e., evolutionary - based on the popularization of belief in science and technical advances, technocratic - aimed at the application of pure sciences, substituting computer systems for routine jobs as well as reflective - aimed at qualitative development of resources of human and social capital for the new man with a creative and critical mindset, innovative and creative not only in being able to respect traditional values and competitively ready but also to cooperate (Woźniak, 2008, pp. 214-215).

\section{References:}

BIEŃKOWSKI, W., RADLO, M. J. (2006). Amerykański model rozwoju. Istota, efektywność i możliwość rozwoju Szkoła Głowna Handlowa, Warszawa.

GOLINOWSKA S., (2002). Europejski model socjalny i otwarta koordynacja polityki społecznej In: Polityka Społeczna, no. 11-12.

GORZELAK, G. (2000). Zewnętrzna interwencja jako czynnik rozwoju lokalnego (na przykładzie programu inicjatyw lokalnych) In: Studia Regionalne i Lokalne, no. 3.

GROSSE, T.G. (2007). Wybrane koncepcje teoretyczne i doświadczenia praktyczne dotyczące rozwoju regionów peryferyjnych In: Ekspertyzy wykonane na zamówienie Ministerstwa Rozwoju Regionalnego na potrzeby opracowania Strategii Rozwoju Społeczno-Gospodarczego Polski Wschodniej do roku 2020, tom I, Ministerstwo Rozwoju Regionalnego, Warszawa.

HRYNIEWICZ, T. J. (2000). Endo i egzogeniczne czynniki rozwoju gospodarczego regionów In: Studia Regionalne i Lokalne, no. 2.

CHAN KIM, W., MAUBORGNE, R. (2005). Strategia błękitnego oceanu. Jak stworzyć wolną przestrzeń rynkową i sprawić, by konkurencja stała się nieistotna, Wyd. MT Biznes sp. zoo. Warszawa.

KLAMUT, M., PANCER-CYBULSKA, E. (ed.) (2006). Spójnośc społeczna, gospodarcza i terytorialna w polityce Unii Europejskiej, Wydawnictwo Akademii Ekonomicznej im. Oskara Langego we Wrocławiu.

KONCEPCJA POLITYKI PRZESTRZENNEGO ZAGOSPODAROWANIA KRAJU 2005 In: Polska 2000 plus, Raport. Hipoteza, t. I, Warszawa, 1995. 
KUKLIŃSKI, A. (1983). Diagnoza gospodarki przestrzennej polski. Wstępne wyniki badań, PWN, Warszawa.

LEWIS, W.W. (2005). Potęga wydajności, CeDeWu, Warszawa.

POLSKA NARODOWE STRATEGICZNE RAMY ODNIESIENIA 2007-2013 WSPIERAJACE WZROST GOSPODARCZY I ZATRUDNIENIE 2006 Ministerstwo Rozwoju regionalnego, sierpień.

POTOCZEK, A. (2003). Polityka regionalna i gospodarka przestrzenna, TNOiK, Toruń.

RACJONALIZACJA FINANSÓW PUBLICZNYCH W POLSCE (2004). Rada Strategii Społeczno-Gospodarczej przy Radzie Ministrów, Warszawa, Raport nr 50.

SZOPA, A., WOŹNIAK M.G. (1997). Zadłużenie zewnętrzne a rozwój przemysłu kraju dłużniczego, Centrum Badań nad Zadłużeniem i Rozwojem, Akademia Ekonomiczna w Krakowie, Kraków.

WIM KOK (2004). The Lisbon Strategy for growth and employment, Report frm the High Level Group Chaired by Wim Kok, November.

WÓJCIK, P. (2007). Wzorce konwergencji regionalnej w Polsce, [w:] Polska w gospodarce światowej - szanse i zagrożenia rozwoju, VIII Kongres Ekonomistów Polskich, 29 - 30 listopada, Warszawa (electronic version).

WOŹNIAK, M.G. (2008). Modernizacja refleksyjna kapitału ludzkiego fundamentalnym wyzwaniem gospodarki i organizacji innowacyjnej, [w]: Organizacje w gospodarce innowacyjnej - aspekty społeczne, prawne, psychologiczne, (red.) W. Pawnik, L. Zbiegień - Maciag, AGH, Uczelniane Wydawnictwa NaukowoDydaktyczne, Kraków, pp. 605-614.

WOŹNIAK, M.G. (2008). Współpraca transgraniczna w modernizacji refleksyjnej kapitału ludzkiego. Znaczenie dla kształtowania spójności społeczno-ekonomicznej In: Spójność społeczno-ekonomiczna a modernizacja regionów trans granicznych, edit. M.G. Woźniak, Wyd. Uniwersytetu Rzeszowskiego, Rzeszów.

WOŹNIAK, M.G., Zadłużenie zagraniczne a restrukturyzacja aparatu wytwórczego Polski, w: B. Jasiński, L. Mesjasz,

KUKLIŃSKI, A. (2009) Gospodarka i Innowacyjność Europy w XXI wieku, Wydawnictwo Uniwersytetu Jagiellońskiego, Kraków. 


\section{THE CHALLENGE OF SOCIO-ECONOMIC COHERENCE FOR POLAND'S} ECONOMIC POLICY IN CONTEXT OF TRANSFORMATION PROCESSES

\section{Michał Gabriel Woźniak}

Cracow University of Economics, Applied Economics Department, ul. Rakowicka 27, 31-510 Kraków, Poland, e-mail: wozniakg@uek.krakow.pl

Abstract: The article focuses on Polish socio-economic coherency in the European and regional context during post WWII period. The author argues that the source of this incoherency are faulty mechanisms, its economic, social and regional policies which were before the transformation based on central coordination of strategies and later, prior to Polish membership in the EU, due to autonomic processes. Much of the weaknesses after accession of Polan to the EU have been due to mixed policies practiced. This has been based on competitive harmony in which economic, social and territorial coherence that is augmented by open coordination methods at union, national, regional and sub-regional levels. It is not sufficient applying socio-economic coherence to processes of eliminating disproportions existing in regional development. Their practical utility requires taking cognizance of the specificity of local material, human and social capital resources. The key issue of socio-economic coherence is harmonizing the development of all aspects of human living.

Key words: socio-economic coherence, economic policy, Poland

JEL Classification: 010, 043, P14

DOI: $10.2478 / v 10135-009-0004-5$ 